\title{
Remodelling sympathetic innervation in rat pancreatic islets ontogeny
}

\author{
Siraam Cabrera-Vásquez ${ }^{1}$, Víctor Navarro-Tableros ${ }^{1}$, Carmen Sánchez-Soto ${ }^{1}$, \\ Gabriel Gutiérrez-Ospina ${ }^{2}$ and Marcia Hiriart*1
}

Address: ${ }^{1}$ Biophysics Department, Instituto de Fisiología Celular - Neuroscience, Universidad Nacional Autónoma de México, Mexico DF, 04510, México and ${ }^{2}$ Cell Biology and Physiology Department, Instituto de Investigaciones Biomédicas, Universidad Nacional Autónoma de México, Mexico DF, 04510, México

Email: Siraam Cabrera-Vásquez - scabrera@ifc.unam.mx; Víctor Navarro-Tableros - vnavarro@ifc.unam.mx; Carmen SánchezSoto - csanchez@ifc.unam.mx; Gabriel Gutiérrez-Ospina - gabo@correo.biomedicas.unam.mx; Marcia Hiriart* - mhiriart@ifc.unam.mx

* Corresponding author

Published: 17 June 2009

BMC Developmental Biology 2009, 9:34 doi:10.1186/147/-213X-9-34

This article is available from: http://www.biomedcentral.com/I47I-2/3X/9/34

(c) 2009 Cabrera-Vásquez et al; licensee BioMed Central Ltd.

This is an Open Access article distributed under the terms of the Creative Commons Attribution License (http://creativecommons.org/licenses/by/2.0), which permits unrestricted use, distribution, and reproduction in any medium, provided the original work is properly cited.
Received: 9 March 2009

Accepted: 17 June 2009

\begin{abstract}
Background: Pancreatic islets are not fully developed at birth and it is not clear how they are vascularised and innervated. Nerve Growth Factor (NGF) is required to guide sympathetic neurons that innervate peripheral organs and also in cardiovascular system and ovary angiogenesis. Pancreatic beta cells of a transgenic mouse that over-expressed NGF in attracts sympathetic hyperinnervation towards them. Moreover, we have previously demonstrated that adult beta cells synthesize and secrete NGF; however, we do not know how is NGF secreted during development, nor if it might be trophic for sympathetic innervation and survival in the pancreas.

We analyzed sympathetic innervation and vasculature development in rat pancreatic islets at different developmental stages; foetal (FI9), early postnatal (PI), weaning period (P20) and adults. We temporarily correlated these events to NGF secretion by islet cells.

Results: Sympathetic fibres reached pancreatic islets in the early postnatal period, apparently following blood vessels. The maximal number of sympathetic fibres (TH immunopositive) in the periphery of the islets was observed at P20, and then fibres entered the islets and reached the core where beta cells are mainly located. The number of fibres decreased from that stage to adulthood. At all stages studied, islet cells secreted NGF and also expressed the high affinity receptor TrkA. Foetal and neonatal isolated islet cells secreted more NGF than adults. TrkA receptors were expressed at all stages in pancreatic sympathetic fibres and blood vessels. These last structures were NGF-immunoreactive only at early stages (foetal and P0).
\end{abstract}

Conclusion: The results suggest that NGF signalling play an important role in the guidance of blood vessels and sympathetic fibres toward the islets during foetal and neonatal stages and could also preserve innervation at later stages of life. 


\section{Background}

Adult pancreatic $\beta$ cells secrete insulin in response to an increase in extracellular glucose. At birth, this response is not fully developed as neonate $\beta$-cells are insensitive to glucose and synthesize and secrete less insulin than adults [1]. Pancreatic islets are innervated by autonomic fibres. In particular, sympathetic neural cell bodies are located in the superior mesenteric and celiac ganglia and are components of the splanchnic nerve and parasympathetic innervation comes from the vagus nerve [2].

Sympathetic innervation plays important roles in the physiology and physiopathology of the endocrine pancreas; nor- and epinephrine inhibit insulin secretion, while stimulate glucagon secretion [3]. Moreover, sympathetic innervation of pancreatic islets is altered in animal models with insulin resistance and type 2 diabetes [4]. However, factors that control sympathetic innervation of pancreatic islets are not clear. The neurotrophin nerve growth factor (NGF) is especially interesting because is synthesized by the peripheral targets of NGF-dependent sympathetic neurons and NGF concentrations are proportional to their innervation density [5]. For example, NGF participates in the innervation of spleen, peripheral lymph nodes and ovaries [6-8] and has also trophic effects on their vascularization [9].

Adult pancreatic beta cells produce and secrete NGF and express NGF high- (TrkA) and low-affinity (p75) receptors during lifespan and NGF is important for a normal islet morphogenesis during prenatal life $[10,11]$ and have trophic effects on $\beta$ cells survival, maturation and insulin secretion $[1,12-14]$. These effects are controlled by autocrine or paracrine mechanisms [15].
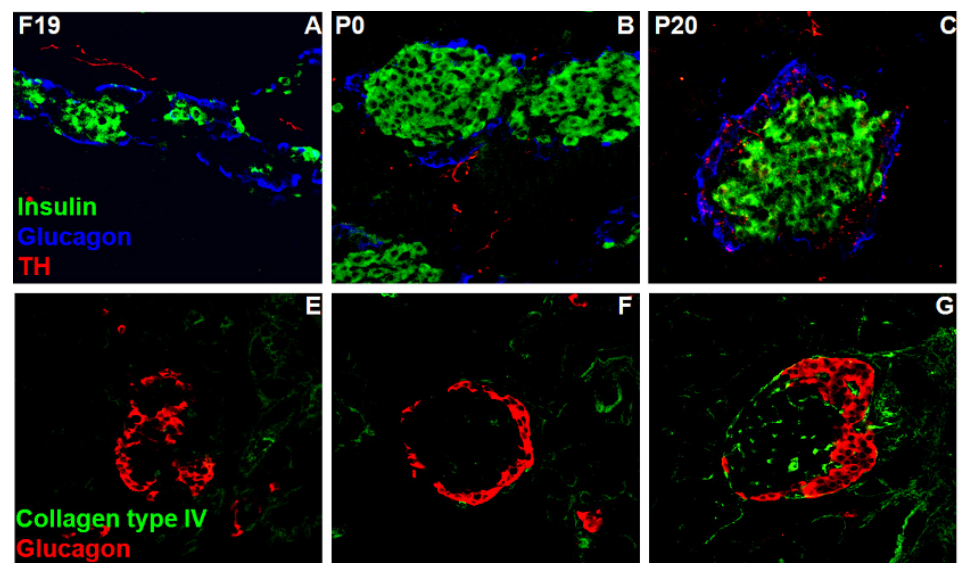

Sympathetic nerves in the pancreas are closely related to blood vessels [16], and nervous fibres are also in part guided by endothelium-derived signals [17]. Trophic interactions among nerve cells, blood vessels and islet cells are fundamental to assure an adequate pancreatic ontogeny and a mature assemblage and function.

NGF could be an important regulator molecule on innervation and vascularisation of the islets. The following observations indicate that this could be the case, 1) NGF overexpression in pancreatic $\beta$ cells causes islet sympathetic hyper-innervation [18]. 2) When islet grafts to diabetic rats are pre-treated with NGF, sympathetic innervation is increased after transplantation [19]. 3) Pancreatic sympathetic innervation is reduced in NGF/Bax double knockout (KO) mice [20]. Finally, NGF in vitro induces development of glucose-induced insulin secretion in neonate rat $\beta$ cells [14] and promotes neuron-like phenotypic changes in foetal and adult $\beta$ cells [21]. The aim of this study was to investigate the morphophysiological relationships between innervation, vascularization and islet morphogenesis and function during ontogeny of rat pancreas, in particular of islets from foetal (F19), early (P1) and late postnatal (P20) stages of development, compared to adults. We also analyzed biosynthesis and secretion of NGF and insulin by $\beta$ cells at these stages.

\section{Results}

\section{The structure of pancreatic islets during ontogeny}

As expected, in mature adult islets glucagon producing $\beta$ cells form a ring-like structure, surrounding insulin-producing $\beta$ cells that fill most of the centre (Fig. 1D and $1 \mathrm{H}$ ). At this stage, we observed that $98 \%$ of islets were delimited by a collagen capsule (Fig. $1 \mathrm{H}$ and additional file 1 ).

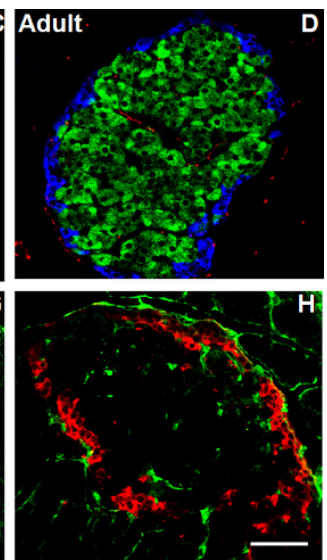

\section{Figure I}

Morphological reorganization of pancreatic islets from prenatal life to adulthood. We localised sympathetic nerve fibres and collagen capsules surrounding the islets by confocal microscopy in longitudinal sections of pancreases. Immunostaining for insulin (green), glucagon (blue), tyrosine hydroxylase (TH; red) and collagen type IV (2 ${ }^{\text {nd }}$ line, green) at different developmental stages (FI9, PI, P20 and adult). Scale bar $=50 \mu \mathrm{m}$. 
In contrast, F19 islets were not formed yet; we only observed large groups of endocrine cells without a capsule and isolated $\alpha$ and $\beta$ cells were scattered through the exocrine pancreas (Fig. 1A and $1 \mathrm{E}$ and additional file 1). Neonatal islets were small, rounded, did not yet presented capsule and were located in close proximity to each other (Fig. 1B and 1F and additional file 1). At P20 most of the endocrine cells had a similar distribution to adults; however, only nearly $26 \%$ of the islets were encapsulated (Fig. $1 \mathrm{C}$ and $1 \mathrm{G}$ and additional file 1 ).

\section{Remodelling sympathetic innervation of islets and NGF}

To identify the sympathetic fibres we used a tyrosinehydroxylase $(\mathrm{TH})$ immunofluorescence. A progressive increase in the relative area occupied by TH positive innervation in the islets was observed between F19 to P20 (Fig. 1 upper panels and Fig 2A). Interestingly, this parameter decreased between P20 and adulthood in the periphery of the islets (Fig. 1 upper panels and Fig. 2B), while increased in the central area (Fig. 1, upper panels and Fig. 2C).

Sympathetic remodelling in this process is probably modulated by NGF produced by islet cells. We analyzed NGF production in situ with an antibody raised against the NGF precursor protein pro-NGF [22-24] in a and $\beta$ cells. Pro-NGF immunoreactivity was observed in both cell types at all stages studied (Fig. 3A and 3B). However, the fluorescence intensity was higher at F19 and P1 than at later ontogenetic stages (additional file 2A and 2B) and when this was studied in isolated islet cells, we confirmed that most of them were $\beta$ cells (insulin positive) and also labelled positive for TrkA receptors (additional file 3). At all stages studied mRNA for NGF is expressed by islet cells (data not shown).

\section{NGF is released by foetal and neonatal islet cells}

We analyzed NGF secretion by ELISA (see Methods). At all studied stages, islet cells secreted NGF (Figure 4A). In accordance to the pro-NGF immunofluorescence observed; NGF secretion was higher at F19 and P1 than at older ages.

NGF secretion may be constitutive or regulated by other way than glucose stimulated insulin secretion, because clearly from figure $4 \mathrm{~B}$, both types of secretions are dissociated. This effect can not be attributed to cultured conditions or reduced cell viability, because P20 and adult cultured $\beta$ cells increased insulin secretion when exposed to high glucose and $\mathrm{KCl}$. Under the last experimental condition, adult $\beta$ cells also increased NGF release.

\section{Pro-NGF and TrkA receptors are expressed for a delimited period in vascular cells}

Vascular cells may also provide guidance cues to axons in their way to reach their targets [17]. Figure 5 shows that blood vessels that enter the islets early in pancreatic
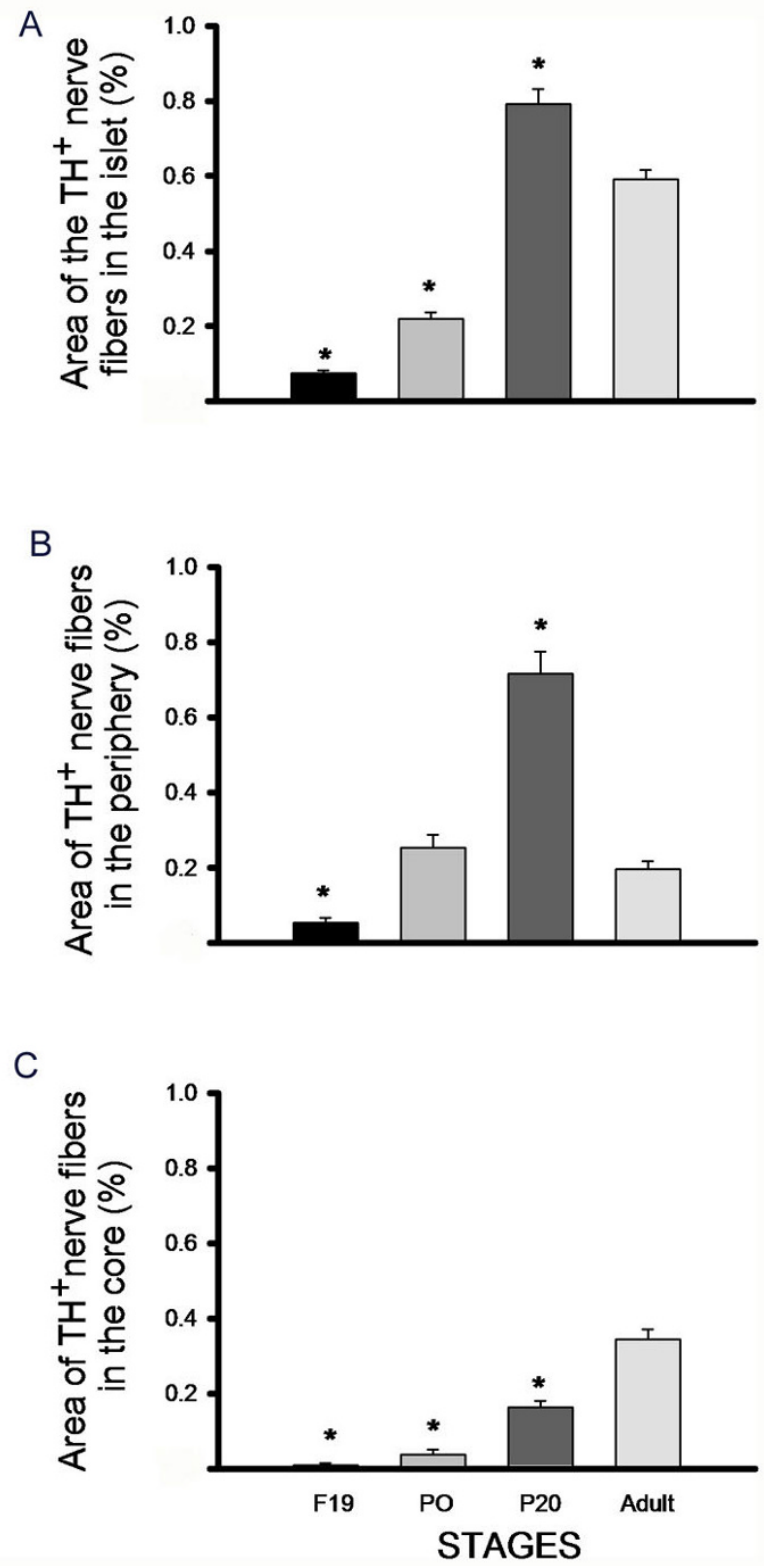

Figure 2

Quantification and analysis of $\mathrm{TH}^{+}$fibres in development of islets. Bar graphs represent A) Percentage of total area occupied by $\mathrm{TH}^{+}$fibres. B) Percentage of peripheral area occupied by $\mathrm{TH}^{+}$fibres. C) Percentage of the core area occupied by $\mathrm{TH}^{+}$fibres. ANOVA ${ }_{\mathrm{p}}<0.00 \mathrm{I}$ compared to adulthood.

ontogeny (F19 and P1) labelled positive to pro-NGF, but not at P20 and thereafter (Fig. 6A and 6B). Blood vessels and sympathetic fibres can respond to NGF, because clear and consistently at all stages both vascular cells and TH positive fibres display immunoreactivity for TrkA receptors (Fig. 7A and 7B). 
A
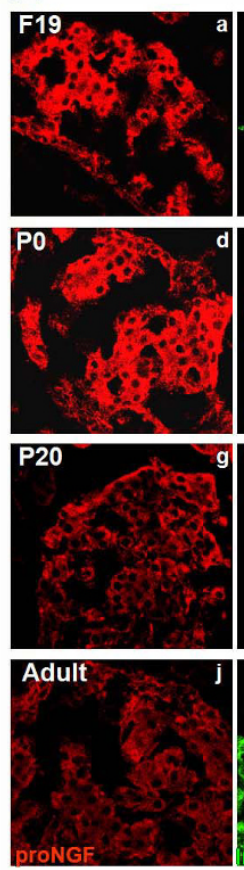
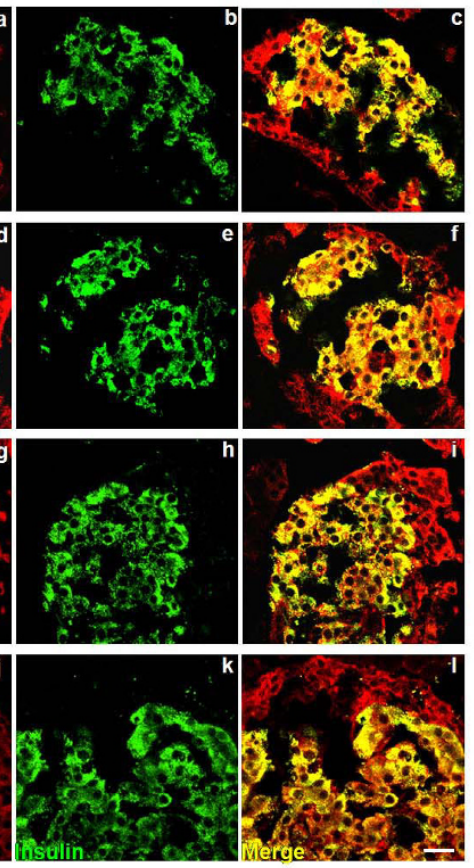

B
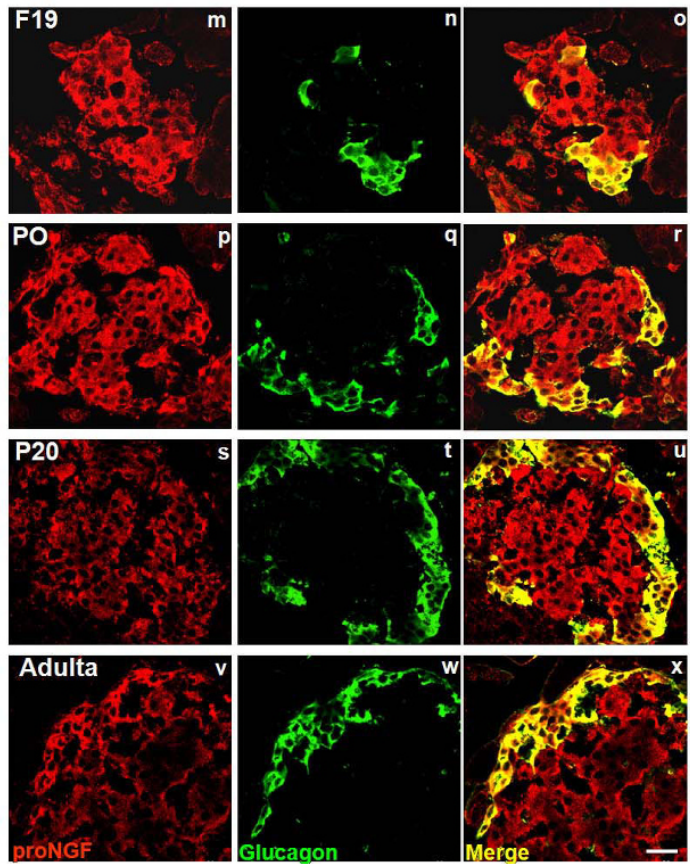

\section{Figure 3}

Colocalization of pro-NGF and insulin or glucagon. (A) Insulin and pro-NGF, (B) glucagon and pro-NGF at different developmental stages. Scale bar $=20 \mu \mathrm{m}$.

\section{Discussion}

We analyzed innervation and function development of pancreatic islets. To our knowledge this is the first analysis of the relationship between innervation, blood vessels and rat pancreatic islets morphology at critical developmental stages. We also examined a possible role of NGF in this process.

Glucose homeostasis in foetal stages depends on the mother [25]. At birth, mammals abruptly need to achieve glucose control on their own, so $\beta$ cells start secreting insulin. Nearly at P20 pups are weaned and they build up an omnivorous diet. These two stages are critical windows for pancreatic development and maturation of glucose induced insulin secretion $[1,26]$. We propose that a capsule or basal membrane surrounding the islets may be taken as one of the maturity markers, because almost all mature islets in adult animals are surrounded by one. It has been suggested that a membrane surrounding the islets could be an important niche for their complete development and survival [27-29]. We observed that a nearly-mature configuration of the pancreatic islets is progressively established during the first 20 days of posnatal life in the rat. However, at this stage nearly $30 \%$ of islets presented a continuous capsule surrounding them, indi- cating that they will continue maturing until adulthood [26].

We observed that pancreatic islets in early development receive an extensive innervation by sympathetic fibres. This innervation is refined later in development. Interestingly, when islets are transplanted to the kidney capsule or intraportally, they develop sympathetic innervation after transplantation $[30,31]$. Moreover, when purified $\beta$ cells are transplanted to the kidney capsule, grafts are progressively innervated mainly by tyrosine hydroxylase-containing nerve fibres. These observations led to suggest that some factors produced by $\beta$ cells mediate islet neurotrophism [31].

We have previously shown that adult pancreatic $\beta$ cells produce and secrete NGF [15]. In this work we observed that this is the case also along ontogeny, which indicates that NGF may be trophic for sympathetic innervation and survival in islets, as it has been observed for other organs [6-8]. NGF secretion in adult cells could also be important for sympathetic fibres maintenance throughout life.

Vascular cells also displayed pro-NGF immunoreactivity, however this is only observed in a critical window around 
A

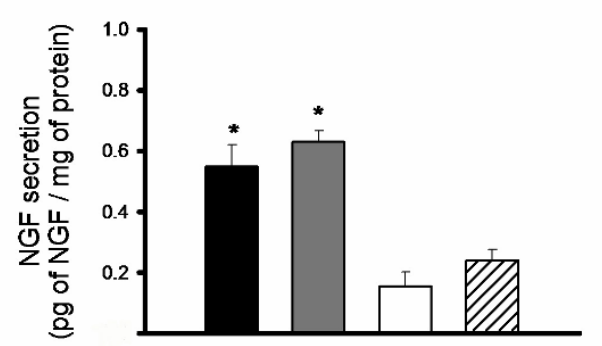

B

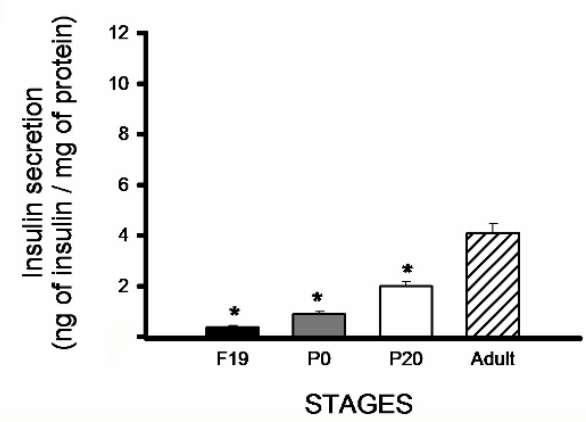

$15.6 \mathrm{mM}$
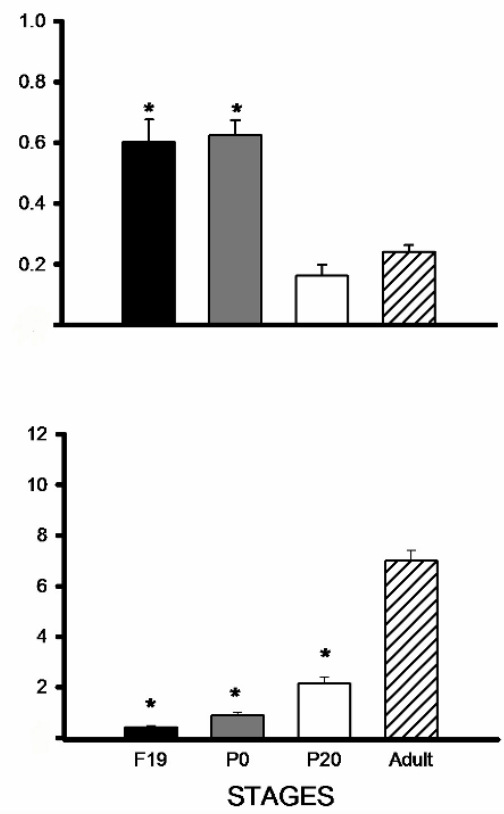

$15.6 \mathrm{mM}+\mathrm{KCl}$
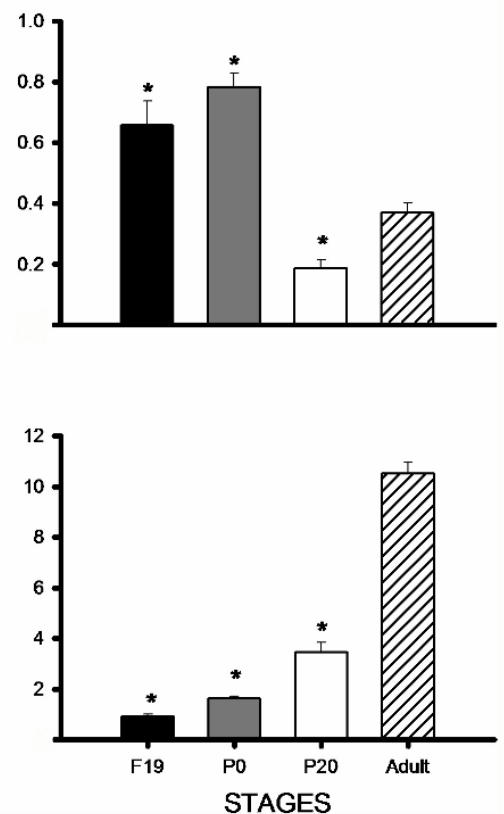

\section{Figure 4}

NGF and insulin secretion at different stages of development. Bar graphs represent NGF (A) or insulin (B) secretion by isolated insular cells under basal or stimulated conditions at different developmental stages. Line I) Basal $5.6 \mathrm{mM}$ glucose; 2 ) Stimulated $15.6 \mathrm{mM}$ glucose and 3) Glucose $15.6 \mathrm{mM}$ plus $20 \mathrm{mM} \mathrm{KCl}$. ANOVA *p < 0.00 I compared to adult cells. Data obtained from 4 independent experiments, each by duplicate.
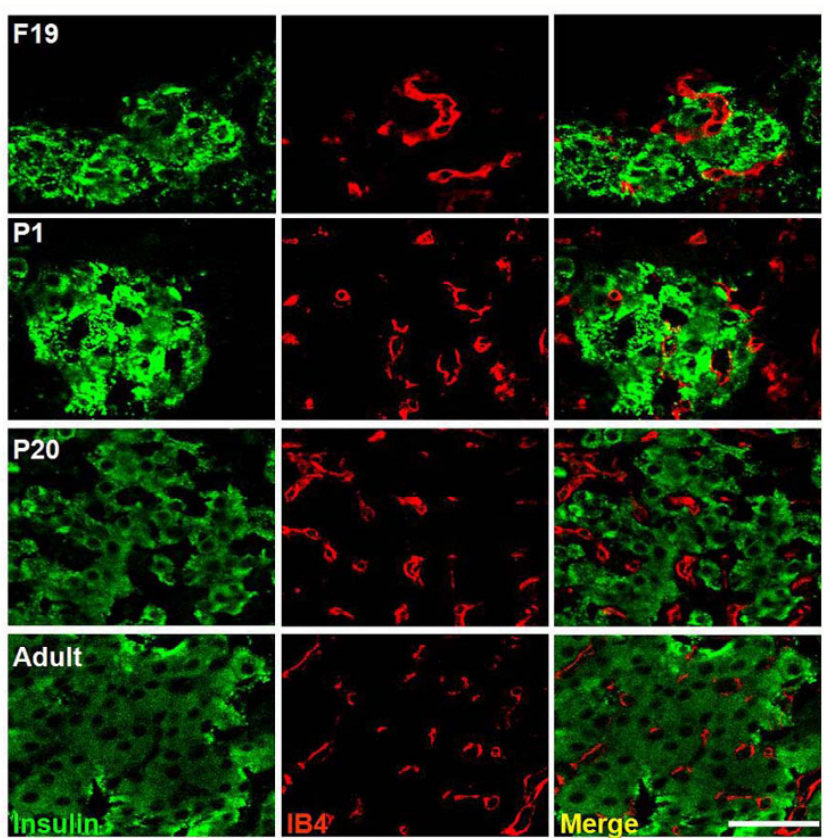

Figure 5

Blood vessel localization in rat islets during development. Insulin (green); Iso-lectin IB4 (red); merge (yellow). Scale bar $=50 \mu \mathrm{m}$. birth. This could also be important for nerve guidance into the islets. There is no perfect marker for blood vessels. We used isolectin IB4 and vimentin. Vimentin expression alone cannot be considered as specific endothelium marker; but it seems to accompany the process of angiogenesis in islets [32]. We also observed that both markers were expressed in blood vessels of developing and mature islets.

NGF produced by $\beta$, $\alpha$ and vascular cells might be acting by auto/paracrine mechanisms because all the studied cells within the islets express TrkA receptors. During development NGF may attract sympathetic fibres as they search for their targets as described for artemin $[17,33]$ and/or promote sympathetic fibre outgrowth within the islet. The presence of TrkA receptors in $\beta$ cells is not new $[10,15,34]$. It is likely that NGF acting through autocrine/paracrine mechanisms promotes $\beta$ cell maturation. In support of this possibility, it has been shown that glucose-induced insulin secretion is increased by NGF after calcium channel translocation to the membrane of the neonate rat $\beta$ cells [35]. The presence of TrkA receptors in vascular cells, on the other hand, might be important for islet blood vessel development because NGF also promotes angiogenesis $[9,36]$ and migration of endothelial cell [37]. 

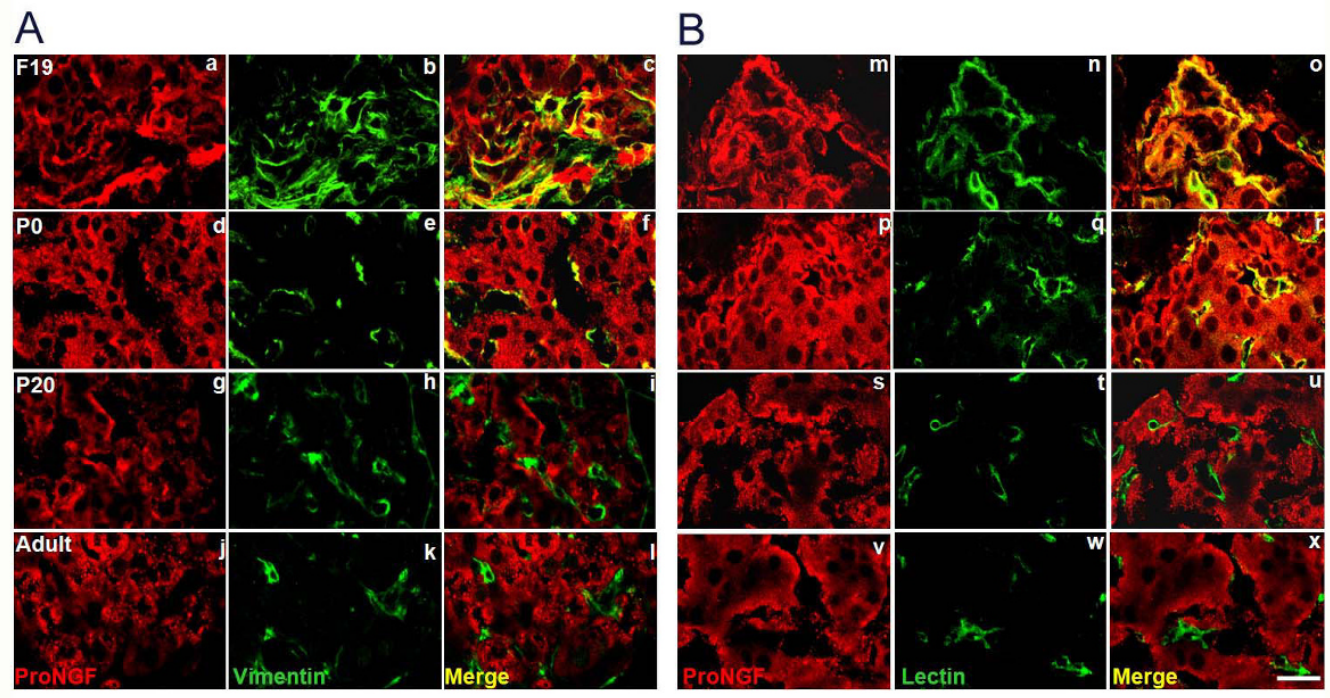

Figure 6

Pro-NGF expression in vascular cells of pancreatic islets. (A) Colocalization of pro-NGF and vimentin (c and $f$ ), (B) pro-NGF and lectin IB4 in different ontogenetic stages (o and $r$ ). Scale bar $=20 \mu \mathrm{m}$.

A

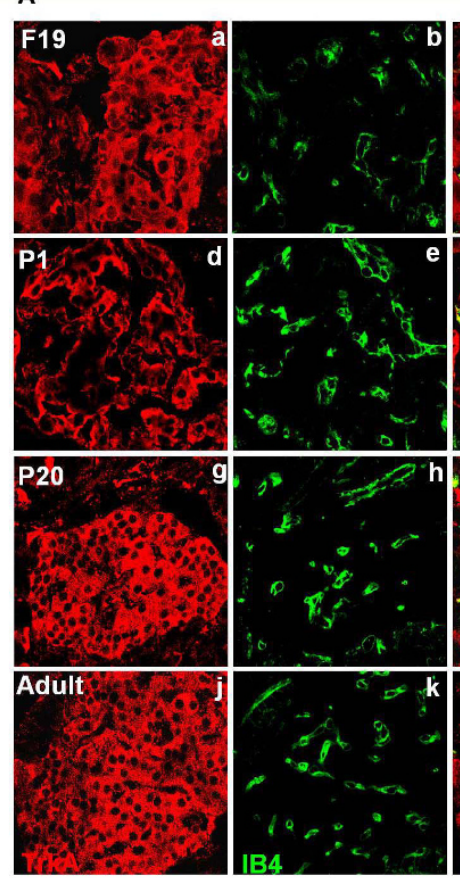

B

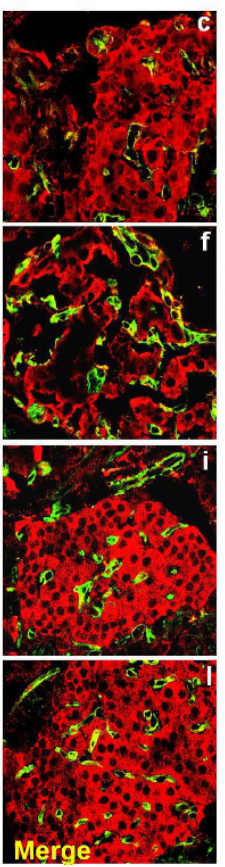

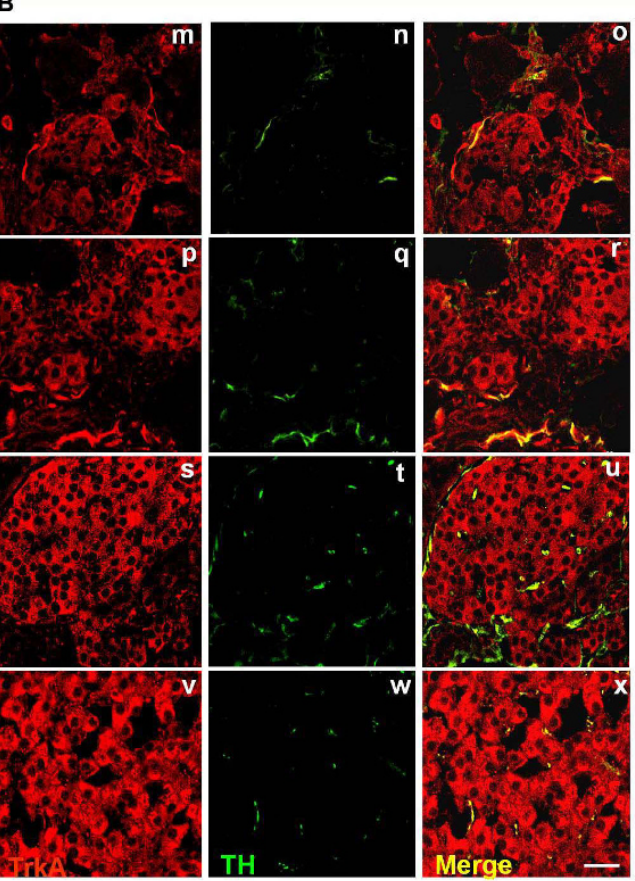

\section{Figure 7}

Expression of TrkA in vascular cells and sympathetic fibres of pancreatic islets. (A) Colocalization of TrkA and vimentin; (B) TrkA and TH at different ontogenetic stages. Colocalization of markers in blood vessels (c, $f$, i and I) or sympathetic fibres (o, $r$, u and $x$ ). Scale bar $=20 \mu \mathrm{m}$. 


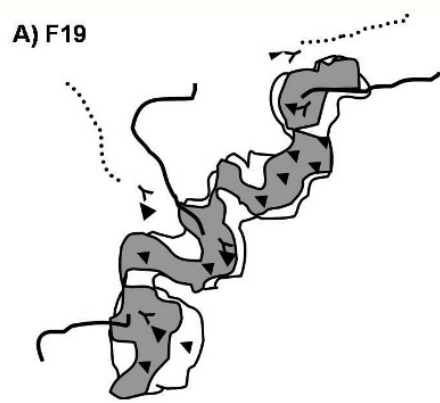

B) P1

C) P20
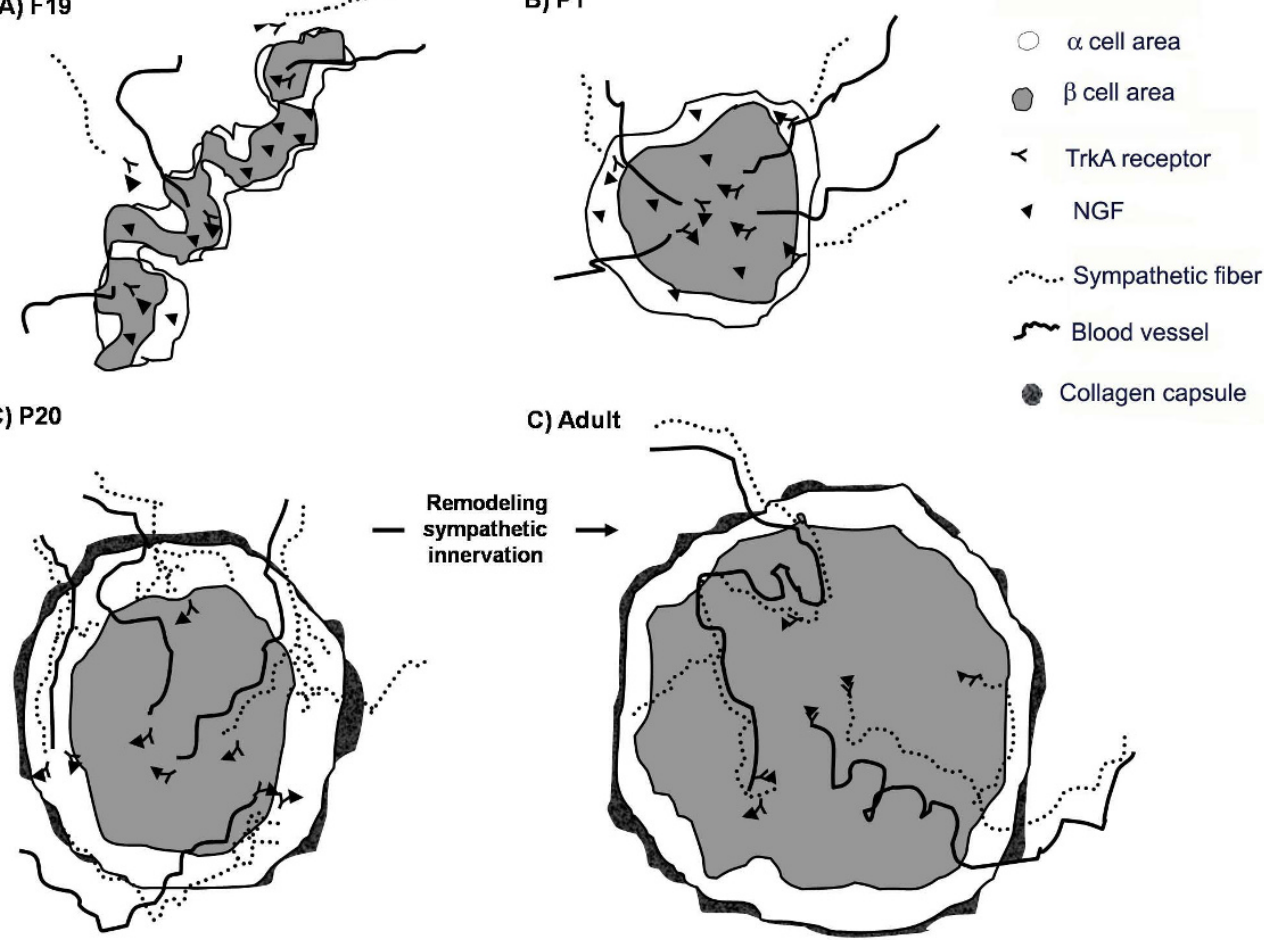

C) Adult

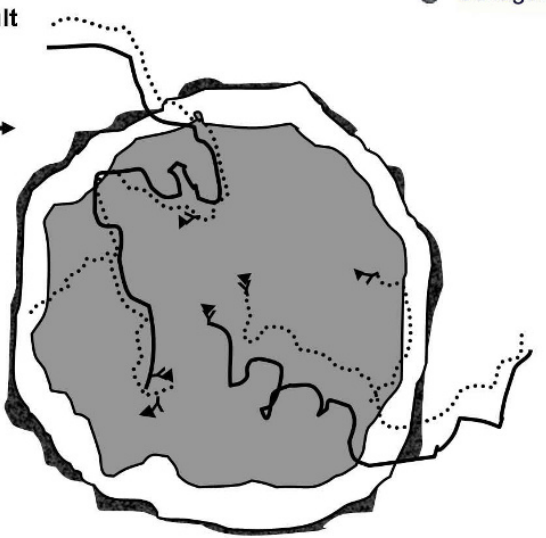

\section{Figure 8}

Model to explain the possible role of NGF in pancreatic development. Our results show that at foetal, early posnatal and P20 stages, the islets are immature in morphology and function. We observed that vasculature is formed first, followed by the innervation of sympathetic fibres and finally, by the capsule, finally conforming the architecture of the mature islet. Between P20 and adult stages a process of remodelling of the sympathetic innervation of the islet, probably by neural competition is observed. NFG could have a role in each the morphofunctional changes that can be received by insular cells, sympathetic fibres and blood vessels due to the presence to TrkA.

These results show that sympathetic innervation is subjected to a strong ontogenetic remodelling during pancreatic development. In general terms, there is a trend of innervation to increase from the perinatal period to P20. After this time, the amount of innervation within the islet decreases. Early hyper-innervation followed by a late elimination of redundant axons mediated through competitive interactions is commonly seen in peripheral targets $[38,39]$. However, it is to our knowledge the first description in pancreatic islets.

At earlier stages, sympathetic fibres are located mainly to the periphery of the islets or $\alpha$ cell compartment and as islets mature, an adjustment in the amount of fibres is accompanied by their relocation near the $\beta$ cell area. Changes of preferred territories of axons to innervate during different ontogenetic stages are common. Transitory targets are used by growing axons while waiting for their definitive target to reach the maturity needed to receive innervation. This might happen in the pancreas since the innervation enters later to the $\beta$ cell compartment, when these cells display more mature functional features [26]; in P28 through adulthood. Adult mice also show more sympathetic fibres located in the periphery of their islets [16].

An interesting issue that deserves consideration relates to the mechanism by which the sympathetic innervation is remodelled. Previous observations that show that NGF overexpression in transgenic mice [18] and knocking out NGF and BAX [20] led to hyper-innervation and hypoinnervation, respectively, strongly suggest that changes in NGF availability might underlie sympathetic nerve remodelling. Accordingly, our results show that insular cells synthesize and release higher amounts of NGF at F19 and P1 than at P20 and after. Interestingly, this pattern of NGF secretion closely paralleled the phases of hyper- and hypo-innervation described in this work. 
Further support for this type of inference is the fact that TrkA-immunoreactivity was observed in islet sympathetic fibres at all ages. We may speculate that the decrease in NGF release in mature beta cells, might be the result of the negative feedback of norepinephrine, secreted by mature sympathetic fibres $[40,41]$.

\section{Conclusion}

In conclusion, these morphological and functional data suggest that NGF plays a pivotal role in pancreatic islet morphogenesis, remodelling and maintenance of sympathetic innervation and development of the vasculature and maturation of a and $\beta$ cells in the islets, as modelled in Fig 8.

There is increasing evidence supporting the causal connection between many adult diseases and an altered ontogeny caused by persistent interactions between the developing organism and its environment early during pre- or postnatal life. A decrease in islet innervation has been shown to be an early target in type 1 diabetes $[42,43]$. Moreover, both homozygous knockout mice for NGF and TrkA resulted in dramatic phenotypes showing poor viability, not surviving beyond few weeks [44].

Interestingly in humans, an autosomal recessive mutation in TrkA gene causes a syndrome of congenital insensitivity to pain with anhydrosis (CIPA; [45], reviewed in [46]). Patients with this mutation show an impaired first-phase of glucose induced-insulin secretion [47]. Finally, a decrease in serum NGF level has been associated with peripheral neuropathy in animal models and humans with diabetes $[48,49]$.

Knowing the roles of NGF in pancreatic islet development, maturation, innervation and function may lead us to new perspectives for understanding and treatment of diabetes mellitus, including better conditions of islets for transplantation.

\section{Methods \\ Animal care}

The experiments were carried out in foetal (F19 day), neonate (1 postnatal day; P1), juvenile (P20) and adult Wistar rats. All postnatal rats were male, and born and raised in temperature and light controlled rooms located in our animal facility. Rats were weaned at P21 and allowed free access to food and water after weaning. Animal protocols were designed following the guidelines provided by the Guide for the Care and Use of Laboratory Animals (National Academy of Sciences, Washington D.C., 1996) and approved by the Animal Care Committee at the Instituto de Fisiología Celular, Universidad Nacional Autónoma de México.

\section{Culture of single insular cells}

Rat foetuses were obtained through a caesarean incision at the age 19 days of gestation. In all the experiments, animals were deeply anesthetised with sodium pentobarbital ( $40 \mathrm{mg} / \mathrm{kg}$ of body weight). After this procedure, foetuses were removed and placed in culture dishes filled with cold D-MEM and rapidly, pancreas was dissected and animals were killed by cervical dislocation.

A similar protocol was followed in rats of different postnatal ages. Once pancreatic islets were obtained by collagenase digestion (collagenase type IV from Worthington; Freehold, NJ), insular cells were desegregated and cultured as described previously [13]. To improve dissociation, the suspension was passed through syringes with needles of decreasing diameter. Dissociated cells were cultured in 24-well culture dishes filled with RPMI 1640 (11.6 mmol/l glucose) supplemented with $10 \%$ foetal calf serum, 200/ml penicillin $\mathrm{G}, 200 \mu \mathrm{g} / \mathrm{ml}$ streptomycin, and $0.5 \mu \mathrm{g} / \mathrm{ml}$ amphotericin $\mathrm{B}$, at $37^{\circ} \mathrm{C}$ and $5 \% \mathrm{CO} 2$ in air. Islet cells were allowed to recover by culturing them overnight before conducting further experiments. Reagents were obtained from the following: Bovine serum albumin (BSA), HEPES, poly-L-lysine, trypsin, from Sigma (St. Louis, MO); tissue culture dishes from Corning (Corning, $\mathrm{NY}$ ); foetal bovine serum (FCS) from Equitech-BIO (Ingram, TX); Hanks' balanced salt solution (HBSS), RPMI 1640 salts, and penicillin-streptomycin-amphotericin B solution from Life Technologies (Grand Island, NY).

\section{Immunofluorescence techniques}

Fresh body-tail segments of rat pancreas were rapidly placed in a buffered solution of paraformaldehyde (4\%) overnight at $4{ }^{\circ} \mathrm{C}$, washed in phosphate buffer-saline (PBS; pH7.4, $0.1 \mathrm{M}$ ), and sequentially transferred to graded (10, 20 and 30\%) solutions of sucrose in PBS for $24 \mathrm{~h}$ in each concentration. Tissue samples were then included in Tissue-Tek-II, cut longitudinally ( 5 or $10 \mu \mathrm{m}$ ) in a cryostat (Leica CM 1900) and mounted on to gelatincoated slides. One tissue section was taken every $200 \mu \mathrm{m}$ along each pancreas segment.

Tissue sections and cultured cells were first incubated with a blocking solution, with $2 \%$ bovine serum albumin (wt/ vol) and $0.1 \%$ Triton X-100 (vol/vol) in PBS-t during 30 min at room temperature. Cell and tissue samples were then incubated with the primary polyclonal antibodies raised against various neural, vascular and pancreatic antigens and worked at different conditions (additional file $4)$; then washed and incubated with the corresponding secondary antibodies conjugated to various fluorophores (additional file 4). This allowed us to develop protocols for single, double or triple immunofluorescence labelling. After a final washing step with PBS, slides were cover- 
slipped with anti-fading agent (DAKO). Negative controls were designed as follows: pre-adsorption with the corresponding antigen ( $1 \mu \mathrm{g}$ peptide/ $\mu \mathrm{g}$ antibody) for the antibodies raised against NGF, insulin or glucagon. For the rest of the antibodies, we omitted primary or secondary antibodies.

To determine the percentage of cells positive to NGF, TrkA, insulin and glucagon, at least 1400 culture cells were counted per marker. Percentage of pancreatic islets that display complete capsules were obtained at different developmental stages, 100 islets were counted per stage.

\section{Endothelial lectin-binding}

Endothelial labelling was also achieved by incubating the tissue sections with TRITC-conjugated Bandeiraea simplicifolia I isolectin B4 (IB4; $45 \mathrm{ug} / \mathrm{ml}$; Sigma), diluted in PBS supplemented with $0.1 \mathrm{mg} / \mathrm{ml} \mathrm{CaCl} 2$ and $\mathrm{MgCl} 2$ [22]. After an extensive wash, all of the slides were coverslipped with anti-fading mounting medium.

To further characterise blood vessels we used vimentin that is an intermediate filament protein (IF). Vimentin is expressed in cells of mesenchymal origin, like are endothelial, fibroblasts and smooth muscle cells, all types present in blood vessels $[23,24]$. We used a monoclonal mouse Anti-Vimentin, Clone VIM 3B4, DAKO (see table S1) according to the manufacturer's instructions.

\section{Quantitative analysis of the sympathetic innervation}

We measured islet innervation area at different stages, in 5 sections, taken each $100 \mu \mathrm{m}$ in the pancreas, per animal ( $\mathrm{n}=8$ animals per data). In each section, 15 different islets were measured. Each islet was delineated and $\mathrm{TH}+$ cells were removed from images using a computer based imaging analysis system (Image J 1.36, Wayne Rasband; National Institutes of Health, Bethesda, MD). The percentage of total pancreatic area and $\alpha$ and $\beta$ areas occupied by $\mathrm{TH}+$ fibres were estimated. The total pancreatic area was calculated by dividing $\mathrm{TH}+$ fibres area by total pancreatic islet area, and $\alpha$ and $\beta$ cell areas. The rate area $\mathrm{TH}+=$ area $\mathrm{TH}+\times 100 /$ islet area $(\alpha$ cell area $+\beta$ cell area $)$.

\section{Confocal microscopy}

Confocal images were obtained using a Fluoview FV1000 laser confocal system (Olympus) attached/interfaced to an Olympus IX81 inverted light microscope with a $40 \times$ glycerol-immersion objective and some images were obtained with zoom 2. We used an Olympus Fluoview FV1000 confocal microscope to observe the sections for Cy5 (excitation 647 nm/DF32, emission 680 nm/DF32), CY3 (excitation $550 \mathrm{~nm} \mathrm{nm/DF32,} \mathrm{emission} 570 \mathrm{~nm} /$ DF32) and FITC (excitation 488 nm/DF32, emission 522 $\mathrm{nm} / \mathrm{DF} 32)$.
For the semiquantitive immunoreactive pro-NGF analysis, all images were taken with the exact same confocal settings to obtain semi-quantitative fluorescent signal and the histograms. Semi-quantification of image intensities was done with Olympus FV10-ASW 1.4 software. Fluorescence measurements were performed automatically by the computer program over the selected areas of interest. The program measures the fluorescence signal of the cytoplasm of the insular cells and obtaining the mean fluorescence in function of the total number of pixels studied in the islets.

Insulin and NGF secretion assays. After obtaining the cells, 200000 islet cells per well were incubated in Hanks' balanced salt solution HBSS (5.6 mM glucose, $0.1 \%$ BSA) for 1 hour at $37^{\circ} \mathrm{C}$. Then, cells were clustered in three experimental groups and incubated, in fresh $5.6 \mathrm{mM}$ glucose-HBSS, $15.6 \mathrm{mM}$ glucose-HBSS or $15.6 \mathrm{mM}$ glucose, $20 \mathrm{mM} \mathrm{KCl}$ in $\mathrm{HBSS}$, for 1 hour at $37^{\circ} \mathrm{C}$. At the end a protease inhibitors was added to each sample (Complete Mini protease inhibitor cocktail; Roche Molecular Biochemical, Mannheim, Germany). NGF and insulin concentrations were then measured by ELISA; EmaxImmunoassay System (Promega, Madison, WI) for NGF and Mercodia ultrasensitive rat insulin ELISA (ALPCO, Windham, NH) for insulin. NGF and insulin levels are reported in pg and ng respectively. All the results were obtained by duplicate and normalised per $\mu \mathrm{g}$ of total protein as estimated by using Bradford assays as recommended by the supplier (Bio-Rad kit 500-0002).

\section{Statistical analysis}

All of the data are reported as means \pm SEM; $n$ denotes the number of cells/or experiments. Because the data distribution fitted a normal curve, we used a one-way ANOVA followed by a Bonferroni's test for multiple comparisons to carry out the statistical analyses (Stat view 4.57; Abacus Concepts, Cary, NC). The p value was set at 0.05 .

\section{Abbreviations}

NGF: nerve growth factor; F19: foetal day 19; P0: postnatal day 0 or neonatal; P20: postnatal day 20

\section{Authors' contributions}

SCV carried out experiments, participated in design of the experiments, draft and final version of the manuscript. VNT carried out experiments of mRNA NGF RT-PCR, cultures and discussion of the manuscript. CSS carried out cultures and insulin secretion analysis, also discussed the manuscript. GGO participated in the design of experiments and quantification of innervation and in discussion and draft version. $\mathrm{MH}$ conceived the study, designed experiments, coordination of participants, writing the manuscript. All authors read and approved the final manuscript. 


\section{Additional material}

\section{Additional file 1}

Pancreatic islets that display complete capsules at different developmental stages.

Click here for file

[http://www.biomedcentral.com/content/supplementary/1471213X-9-34-S1.pdf]

\section{Additional file 2}

Ontogeny Pro-NGF expression. (A) Pro-NGF expression in the pancreas at different developmental stages. (B) Bars represent mean fluorescence intensity (arbitrary units). ANOVA * $p=<0.001$ relative to adulthood, $n=8$ different animals per developmental stage. Scale bar $=20 \mathrm{~m}$. Click here for file

[http://www.biomedcentral.com/content/supplementary/1471213X-9-34-S2.pdf]

\section{Additional file 3}

Percentage of cells immunoreactive to NGF, TrkA, insulin and glucagon at F19.

Click here for file

[http://www.biomedcentral.com/content/supplementary/1471-

213X-9-34-S3.pdf]

\section{Additional file 4}

Antibodies used in the experiments.

Click here for file

[http://www.biomedcentral.com/content/supplementary/1471-

213X-9-34-S4.pdf]

\section{Acknowledgements}

We are very grateful to Selda Gezginci-Oktayoglu, Alvaro Caso-Chávez and Dr. Rocío Aguilar-Chongtay for the discussion and revision of the manuscript; Diana Millán, Felix Sierra, Federico Jandete, Alejandra AlvarezTinoco, and Dagoberto Tapia, for technical assistance; Dr. Claudia RiveraCerecedo and Dr. Hector Malagón for providing animal management and care; Dr. Araceli Patrón Soberano, Gabriel Orozco Hoyuela and Rodolfo Paredes from the Unit of Microscopy, and to Ana Ma. Escalante, Adrián Aguilera and Francisco Perez-Eugenio from the Computing Unit, all Units are in the Instituto de Fisiología Celular, UNAM.

This work was supported by DGAPA 229407 (Universidad Autónoma de México), Facultad de Medicina, Universidad Nacional Autónoma de México SDI.PTID.05.6 and CONACYT FI-60065 to MH.

This study was performed in partial fulfilment of the requirements for the $\mathrm{PhD}$ degree in Biomedical Sciences (Universidad Nacional Autónoma de México) of Siraam Cabrera-Vásquez that received fellowships from Universidad Autónoma Benito Juárez de Oaxaca, PROMEP, and CONACYT (I85762).

\section{References}

I. Navarro-Tableros V, Fiordelisio T, Hernandez-Cruz A, Hiriart M Physiological development of insulin secretion, calcium channels, and GLUT2 expression of pancreatic rat beta-cells. Am J Physiol Endocrinol Metab 2007, 292(4): El018-1029.

2. Salvioli B, Bovara M, Barbara G, De Ponti F, Stanghellini V, Tonini M, Guerrini S, Cremon C, Degli Esposti M, Koumandou M, et al.: Neu- rology and neuropathology of the pancreatic innervation. Jop 2002, 3(2):26-33.

3. Ahren B: Autonomic regulation of islet hormone secretion implications for health and disease. Diabetologia 2000 43(4):393-4I0.

4. Ahren B: Glucagon secretion in relation to insulin sensitivity in healthy subjects. Diabetologia 2006, 49(1): II7-122.

5. Bjerre B, Björklund A, Mobley W, Rosengren E: Short- and longterm effects of nerve growth factor on the sympathetic nervous system in the adult mouse. Brain Research 1975, 94(2):263-277.

6. Carlson SL, Albers KM, Beiting DJ, Parish M, Conner JM, Davis BM NGF modulates sympathetic innervation of lymphoid tissues. J Neurosci 1995, I 5(9):5892-5899.

7. Dissen GA, Romero C, Paredes A, Ojeda SR: Neurotrophic control of ovarian development. Microsc Res Tech 2002, 59(6):509-5।5.

8. Lara HE, McDonald JK, Ojeda SR: Involvement of nerve growth factor in female sexual development. Endocrinology 1990, I 26(I):364-375.

9. Lazarovici P, Marcinkiewicz C, Lelkes PI: Cross talk between the cardiovascular and nervous systems: neurotrophic effects of vascular endothelial growth factor (VEGF) and angiogenic effects of nerve growth factor (NGF)-implications in drug development. Curr Pharm Des 2006, I 2(21):2609-2622.

10. Kanaka-Gantenbein C, Dicou E, Czernichow P, Scharfmann R: Presence of nerve growth factor and its receptors in an in vitro model of islet cell development: Implication in normal islet morphogenesis. Endocrinology 1995, 136(7):3154-3162.

II. Kanaka-Gantenbein C, Tazi A, Czernichow P, Scharfmann R: In vivo presence of the high affinity nerve growth factor receptor Trk-A in the rat pancreas: differential localization during pancreatic development. Endocrinology 1995, 136(2):76I-769.

12. Hiriart M, Aguilar-Bryan L: Channel regulation of glucose sensing in the pancreatic beta-cell. Am J Physiol Endocrinol Metab 2008, 295(6): EI 298-I306.

13. Navarro-Tableros V, Sanchez-Soto MC, Garcia S, Hiriart M: Autocrine regulation of single pancreatic beta-cell survival. Diabetes 2004, 53(8):2018-2023.

14. Rosenbaum T, Sanchez-Soto MC, Hiriart M: Nerve growth factor increases insulin secretion and barium current in pancreatic beta-cells. Diabetes 200I, 50(8): I755-1762.

15. Rosenbaum T, Vidaltamayo R, Sanchez-Soto MC, Zentella A, Hiriart $M$ : Pancreatic beta cells synthesize and secrete nerve growth factor. Proc Natl Acad Sci USA 1998, 95(I 3):7784-7788.

16. Burris RE, Hebrok M: Pancreatic innervation in mouse development and beta-cell regeneration. Neuroscience 2007 , I 50(3):592-602.

17. Honma Y, Araki T, Gianino S, Bruce A, Heuckeroth R, Johnson E, Milbrandt J: Artemin is a vascular-derived neurotropic factor for developing sympathetic neurons. Neuron 2002, 35(2):267-282.

18. Edwards RH, Rutter WJ, Hanahan D: Directed expression of NGF to pancreatic [beta] cells in transgenic mice leads to selective hyperinnervation of the islets. Cell 1989, 58(I):16I-170.

19. Reimer MK, Mokshagundam SP, Wyler K, Sundler F, Ahren B, Stagner II: Local growth factors are beneficial for the autonomic reinnervation of transplanted islets in rats. Pancreas 2003, 26(4):392-397.

20. Glebova NO, Ginty DD: Heterogeneous requirement of NGF for sympathetic target innervation in vivo. I Neurosci 2004, 24(3):743-751.

21. Vidaltamayo R, Sánchez-Soto MC, Rosenbaum T, Martínez-Merlos T, Hiriart M: Neuron-like phenotypic changes in pancreatic Bcells induced by NGF, FGF and dbcAMP. Endocrine 1996, 4:19-26.

22. Lessmann V, Gottmann K, Malcangio M: Neurotrophin secretion: current facts and future prospects. Prog Neurobiol 2003, 69(5):34I-374.

23. Lu B, Pang PT, Woo NH: The yin and yang of neurotrophin action. Nat Rev Neurosci 2005, 6(8):603-6I4.

24. Lim KC, Tyler CM, Lim ST, Giuliano R, Federoff HJ: Proteolytic processing of proNGF is necessary for mature NGF regulated secretion from neurons. Biochem Biophys Res Commun 2007, 36 I (3):599-604.

25. King JC: Maternal obesity, metabolism, and pregnancy outcomes. Annu Rev Nutr 2006, 26:27I-29I. 
26. Aguayo-Mazzucato C, Sanchez-Soto C, Godinez-Puig V, GutierrezOspina G, Hiriart M: Restructuring of pancreatic islets and insulin secretion in a postnatal critical window. PLOS ONE 2006, I:e35.

27. Janssen SW, Hermus AR, Lange WP, Knijnenburg Q, Laak JA van der, Sweep CG, Martens G], Verhofstad AA: Progressive histopathological changes in pancreatic islets of Zucker Diabetic Fatty rats. Exp Clin Endocrinol Diabetes 2001, I 09(5):273-282.

28. Nikolova G, Strilic B, Lammert E: The vascular niche and its basement membrane. Trends Cell Biol 2007, I 7(I): 19-25.

29. Irving-Rodgers HF, Ziolkowski AF, Parish CR, Sado Y, Ninomiya $Y$ Simeonovic C], Rodgers RJ: Molecular composition of the periislet basement membrane in NOD mice: a barrier against destructive insulitis. Diabetologia 2008, 5 I(9): |680- |688.

30. Gardemann A, Jungermann K, Grosse V, Cossel L, Wohlrab F, Hahn HJ, Blech W, Hildebrandt W: Intraportal transplantation of pancreatic islets into livers of diabetic rats. Reinnervation of islets and regulation of insulin secretion by the hepatic sympathetic nerves. Diabetes I994, 43(I I): I 345-I 352.

31. Myrsen U, Keymeulen B, Pipeleers DG, Sundler F: Beta cells are important for islet innervation: evidence from purified rat islet-cell grafts. Diabetologia 1996, 39(I):54-59.

32. Vasir B, Reitz P, Xu G, Sharma A, Bonner-Weir S, Weir GC. Effects of diabetes and hypoxia on gene markers of angiogenesis (HGF, cMET, uPA and uPAR, TGF-alpha, TGF-beta, bFGF and Vimentin) in cultured and transplanted rat islets. Diabetologia 2000, 43(6):763-772.

33. Damon DH, Teriele JA, Marko SB: Vascular-derived artemin: a determinant of vascular sympathetic innervation? Am J Physiol Heart Circ Physiol 2007, 293(I):H266-273.

34. Miralles F, Philippe P, Czernichow P, Scharfmann R: Expression of nerve growth factor and its high-affinity receptor Trk-A in the rat pancreas during embryonic and fetal life. J Endocrinol | 998, I 56(3):431-439.

35. Navarro-Tableros V, Fiordelisio T, Hernandez-Cruz A, Hiriart M: Nerve growth factor promotes development of glucoseinduced insulin secretion in rat neonate pancreatic beta cells by modulating calcium channels. Channels (Austin) 2007, I(6):408-4 I6

36. Julio-Pieper M, Lara HE, Bravo JA, Romero C: Effects of nerve growth factor (NGF) on blood vessels area and expression of the angiogenic factors VEGF and TGFbetal in the rat ovary. Reprod Biol Endocrinol 2006, 4:57.

37. Dolle JP, Rezvan A, Allen FD, Lazarovici P, Lelkes PI: Nerve growth factor-induced migration of endothelial cells. J Pharmacol Exp Ther 2005, 3 I 5(3): | 220- I 227

38. Deppmann CD, Mihalas S, Sharma N, Lonze BE, Niebur E, Ginty DD: A model for neuronal competition during development. Science 2008, 320(5874):369-373

39. Silva AM, Queiroz DB, Castro Neto EF, Naffah-Mazzacoratti Mda G, Godinho RO, Porto CS, Gutierrez-Ospina G, Avellar MC: Segmentspecific decrease of both catecholamine concentration and acetylcholinesterase activity are accompanied by nerve refinement in the rat cauda epididymis during sexual maturation. J Androl 2002, 23(3):374-383.

40. Nisoli E, Tonello C, Benarese M, Liberini P, Carruba MO: Expression of nerve growth factor in brown adipose tissue: implications for thermogenesis and obesity. Endocrinology 1996 I 37(2):495-503.

4I. Peeraully MR, Jenkins JR, Trayhurn P: NGF gene expression and secretion in white adipose tissue: regulation in 3T3-LI adipocytes by hormones and inflammatory cytokines. Am J Physiol Endocrinol Metab 2004, 287(2):E331-339.

42. Persson-Sjogren S, Holmberg D, Forsgren S: Remodeling of the innervation of pancreatic islets accompanies insulitis preced ing onset of diabetes in the NOD mouse. J Neuroimmunol 2005, I 58(I-2): 128-137.

43. Saravia F, Homo-Delarche F: Is innervation an early target in autoimmune diabetes? Trends Immunol 2003, 24(I I):574-579.

44. Crowley C, Spencer SD, Nishimura MC, Chen KS, Pitts-Meek S, Armanini MP, Ling LH, McMahon SB, Shelton DL, Levinson AD, et al.: Mice lacking nerve growth factor display perinatal loss of sensory and sympathetic neurons yet develop basal forebrain cholinergic neurons. Cell 1994, 76(6): I001-I0I I

45. Indo Y: Genetics of congenital insensitivity to pain with anhidrosis (CIPA) or hereditary sensory and autonomic neuropa- thy type IV. Clinical, biological and molecular aspects of mutations in TRKA(NTRKI) gene encoding the receptor tyrosine kinase for nerve growth factor. Clin Auton Res 2002 I 2(Suppl I):120-32.

46. Chao MV, Rajagopal R, Lee FS: Neurotrophin signalling in health and disease. Clin Sci (Lond) 2006, I I O(2): I67-I73.

47. Schreiber R, Levy J, Loewenthal N, Pinsk V, Hershkovitz E: Decreased first phase insulin response in children with congenital insensitivity to pain with anhidrosis. J Pediatr Endocrinol Metab 2005, I 8(9):873-877.

48. Faradji V, Sotelo J: Low serum levels of nerve growth factor in diabetic neuropathy. Acta Neurol Scand 1990, 8 I (5):402-406.

49. Tomlinson MJ, White A, Barratt CL, Bolton AE, Cooke ID: The removal of morphologically abnormal sperm forms by phagocytes: a positive role for seminal leukocytes? Hum Reprod 1992, 7(4):517-522.
Publish with Bio Med Central and every scientist can read your work free of charge

"BioMed Central will be the most significant development for disseminating the results of biomedical research in our lifetime. "

Sir Paul Nurse, Cancer Research UK

Your research papers will be:

- available free of charge to the entire biomedical community

- peer reviewed and published immediately upon acceptance

- cited in PubMed and archived on PubMed Central

- yours - you keep the copyright
BioMedcentral 